\title{
The Settlement of Sharia Banking Dispute based on Legal Culture as a Practice of Indonesian Islamic Moderation
}

\author{
Erie Hariyanto \\ (Faculty of Syariah Institut Agama Islam Negeri Madura, Jl. Raya Panglegur, Km. \\ 04 Tlanakan Pamekasan 69371, Email: erie@iainmadura.ac.id)
}

\begin{abstract}
:
Islamic banking and religious courts have a very close-knit network. Both Islamic banking serving as Islamic financial intermediation institution and religious courts as special courts with authority to resolve the dispute of Islamic banking similarly stressed on applying the sharia principles in the operation. They are expected to sinergically rely on sharia principles. The philosophical basic of religious courts' authority in dispute settlement of sharia banking is to create a harmony between the execution of contract and material law based on the principles of sharia with religious courts as an institutiton for Moslem justice-seekers so that the disputes can be resolved wholly (kafâ'ah) and consistently (istiqâmah) through court rulings upholding the culture of law. The meeting of values of sharia and culture living in society produces harmony in terms of Islamic banking dispute settlement.
\end{abstract}

\section{Keywords:}

Dispute Settlement, Sharia banking, Culture of law

\begin{abstract}
Abstrak:
Keberadaan perbankan syariah dan peradilan agama memiliki keterkaitan yang sangat erat. Perbankan syariah sebagai lembaga intermediasi keuangan syariah dan peradilan agama sebagai lembaga peradilan khusus yang mempunyai kewenangan ablosut menyelesaikan sengketa perbankan syariah sama-sama menekankan menerapkan prinsip-prinsip syariah dalam operasionalnya. Perbankan syariah dan peradilan agama diharapkan dapat bersinergis dengan berpegang pada prinsip syariah. Dasar filosofis Kewenangan peradilan agama dalam penyelesaian sengketa perbankan syari'ah adalah agar terciptanya keselarasan antara pelaksanaan akad dan hukum materiil yang berlandaskan prinsip-prinsip syariah dengan lembaga peradilan
\end{abstract}

al-1hkâm Vol.14 No.2 Desember 2019

DOI $10.19105 /$ al-ihkam.v14i2.1888 
Erie Hariyanto

agama yang memang merupakan wadah bagi pencari keadilan yang beragama islam sehingga sengketa perbankan syariah dapat diselesaikan secara kafä'ah dan istiqāmah melalui putusan pengadilan yang mengedepankan budaya hukum. Pertemuan nilai syariah dan budaya yang hidup dalam masyarakat menghasilkan harmoni dalam penyelesaian sengketa perbankan syariah

\author{
Kata Kunci: \\ Penyelesain Sengketa, Perbankan Syari ah, Budaya Hukum
}

\title{
Introduction
}

Article of 24 and 25 in 1945 Law about implementation of judicature mentioned that in order to enforce the law and justice, an independent judicial power was established. The Supreme Court oversees the judiciary in general, religious, military and state administrative courts. ${ }^{1}$ In addition to the Judicial Power Law, the Law of the Supreme Court also contributed to the justice system, namely: Act No. 3, 2009 about the Second Amendment on the Act No. 14, 1985 on the Supreme Court (hereinafter referred to as the Law of the Supreme Court)

When the religious courts had not yet been under the Supreme of Court management, it was called the religious court at the first level, while appellate is called High Religious Court. Before, both were different in name. "The different names were then put together by the Minister of Religion Affair's Decision Letter No. 6 of 1980, on January 28, 1980 into the name the Religious Court for the first level and the High Court of Religion for the appellate". ${ }^{2}$

Prior to the enactment of the Religious Courts Law, the authority of religious courts throughout Indonesia is on the marriage law, as stated in Article 63 paragraph (1) of the Marriage Law. It mentioned that religious courts are competent in the areas of marriage for Moslem citizens. However, article 63 paragraph (1) was mitigated

1Taufiq Hamami, Peradilan Agama dalam Reformasi Kekuasaan Kehakiman di Indonesia (Jakarta: Tatanusa, 2013), 17-18.

2Erfaniah Zahriah, Peradilan Agama Indonesia: Sejarah Pemikiran dan Realita (Malang: UIN Maliki Press, 2009), 26 
by paragraph (2) stating that any religious court decision must be confirmed by the state court.

It means that to be able to do execute the verdict, religious courts need to get auhority from the state courts or so called (executoir verklaring). One of reasons for this is because at that time, religious courts had not had any confiscation staffs like those of state courts. Among others, this implied that before the law of religios court had been enacted, the religious court had not been in the same position as other courts.

Therefore, the enactment of the Law of Religious Court had also created a governing entity within the framework of religious courts and national legal order. "Moslems which is a part of Indonesian population are given the opportunity to obey Islamic law as a part of divine teachings of their religion". ${ }^{3}$

Last 2006, as one of four institutions under the management of the supreme court, religious court got additional and strategic authority, which is ability to adjudicate any disputes. This was preceded by the ratification of Religious Courts Law.

The amendments to the Religious Courts Act was motivated by the emergence of new legislation, namely Law No. 4 of 2004 on Judicial Power as an organic law on Article 24 of the Constitution of 1945 PostAmendment with the one-stop system (one roof system). ${ }^{4}$

Historically, religious court had long been existed in Indonesia even before the Dutch government went into the archipelago. It kept growing and going on in accordance with the rhytm of governments' policies in each period. The important milestone of religious courts development was signed by the publication of religious courts law, the Law on Islamic Banking and strengthened by the Constitutional Court Decision No. 93/PUU-X/2012 about Elucidation of Article 52 Paragraph (2) of the Law of Islamic Banking as the legal basis for religious courts authority to resolve disputes in the sharia economic field.

The dispute of resolution processes in the religious court in fact still found some problems. A real example is the lack of procedural

3Mohammad Daud Ali dan Habibah Daud, Lembaga-lembaga Islam di Indonesia, (Jakarta: Raja Grafindo Persada, 1995), 120.

4Mardani, Hukum Acara Perdata Peradilan Agama, (Jakarta: Sinar Grafika, 2007), 65. 
law specific of religious courts, so the use of law applicable in general court can not be avoided. The existence of the law becomes much more urgent when the dispute over the Islamic banking had been held by religious court while the businessmen are not only Moslems. ${ }^{5}$

The development of religious courts, together with the growth of Islamic banks as part of an Islamic economic system, began to emerge in the mid-20th century. It was signed by the establishment of Mit Ghamr Local Saving banks in Egypt. However, due to the political situation at that time, the bank was taken over by the National Bank Of Egypt and the Central Bank of Egypt the in 1967 then operated usury based banking system. Later on in 1972, a non-usury based banking system was reintroduced through the establishment of the Nasser Social Bank in Egypt.

Another milestone for the development of sharia bank was founded by the Islamic Development Bank (IDB) in Jeddah in 1975 initiated by member countries of the Organization of the Islamic Conference (OIC). IDB later played an important role in meeting the needs of Moslem countries funds for development. Finally, the establishment of IDB motivated many countries to set up Islamic financial institutions. As a result, at the late 1970 's and early 1980-90s decade, Islamic banking have sprung up in Egypt, Sudan, the Gulf countries, Iran, Pakistan, Malaysia, Bangladesh, and Turkey. ${ }^{6}$

In Indonesia, it is fair to say that the emergence of Islamic banking was too late compared to other countries with dominant Moslem population. The big number of Indonesian Moslem $( \pm 85 \%$ of 237 million Indonesian) provides a good opportunity for Islamic banking sector's rapid progress. "Through presenting alternative financial instruments and banking to customers of Indonesian Moslems, the government was getting serious in giving attention to the growth of Islamic banks in Indonesia". ${ }^{7}$

Following the emergence of sharia banks in other countries, a discussion of the sharia bank as the economic pillar of Islam took

5Erie Hariyanto, "Kedudukan Bank Syariah dalam Sistem Perbankan di Indonesia" in Iqtishadia: Jurnal Ekonomi dan Perbankan Syariah STAIN Pamekasan, Vol. 3 No. 2 Desember 2016, 214

6Abdullah Saeed, Menyoal Bank Syari'ah. (Jakarta: Paramadina), 2004, 16.

7Bank Indonesia, Panduan Investasi Perbankan Syariah Indonesia, (Jakarta: Bank Indonesia, 2007), 9. 
place in the early 1980s. "Concretely, in 1991, there formed a Deed of Establishment of Muamalat Bank of Indonesia as a result of the national congress of the Indonesian Ulama Council in 1990 about the plan of establishment of Islamic banks in Indonesia". ${ }^{8}$

The Indonesian Sharia Bank was officially introduced in 1992 in line with the enactment of Law No. 7 of 1992 concerning banking (hereinafter referred to as the Banking Act). The emergence of this legislation indicates the agreement among Indonesians to implement a dual banking system in Indonesia. This stage was also the phase of introduction to banking system. ${ }^{9}$

The banking law does not explicitly mention the existence of the so-called sharia bank. There are only two chapters to rely upon, namely article 6 letter $(\mathrm{m})$ concerning the scope of general banking and article 13 letter (c) regarding to the scope of rural banks (bank perkreditan rakyat). Both two mention the same content, which is "providing financing for customers based on the principle of profit sharing in line with conditions set out in government regulations". ${ }^{10}$

The activity of Islamic banking is mainly on carrying out both conventionally and sharia principle based business activities in providing services in payment traffic. "This relates to the legislation mentioning that sharia banking gets much opportunities to run business activities, including enabling conventional commercial banks to open branch offices with sharia principle based system". ${ }^{11}$ Meanwhile, the principles of sharia means the rule of Islamic law based on the agreement between the bank and other parties for

8Muhammad Syafi'i Antonio, Bank Syari'ah Wacana Ulama dan Cendikiawan, (Jakarta: Tazkia Institut, 1999), 278.

${ }^{9}$ Karnaen Perwataatmadja, Bank dan Asuransi Islam di Indonesia, (Jakarta: Kencana, 2005), 1-3

10Abdurrahman, Eksistensi Perbankan Syari'ah dalam Pembinaan Ekonomi Umat dalam Prospek Bank Syariah di Indonesia, (Bandung :PPHIM, Bandung, 2005), 26

${ }^{11} \mathrm{On}$ the basis of the Banking Act, then stood Shariah Bank Mandiri and some comventional banks opening branches of Shariah such as BNI, BRI, Bank IF, Bank Bukopin, Bank Danamon, BPD Jabar and so forth. Even, there found a a foreign bank opened sharia branch, ie HSBC Bank. See, Hasanuddin, "Penyelesaian Sengketa dalam Perbankan Syar'ah", paper presented at the Seminar on Islamic Banking as A Means of Empowerment organized by the Economic Democracy, BPHN Departemen Kehakiman dan HAM in cooperation with FH Universitas Andalas Padang, Kanwil Departemen Kehakiman and HAM West Sumatra Province June 29-30, 21 
storage, financing business activities, or other activities in accordance with the sharia law. It is clear, therefore, that Indonesia applies two banking systems, i.e., conventional system and provisions of the sharia of Islam principle based system.

Legal certainty is felt much more influencing for both observers and users of Islamic banking services after the Promulgation of Law No. 21 of 2008 concerning Islamic banking (hereinafter referred to as Islamic Banking Act). Since then, Islamic banking becomes one of solutions of national economy in which serves as one of leading factors in national stability. The whole national problems can be fixed firstly from sharia-based economy.

The Islamic banking activity is firmly regulated in the Banking Act in conjunction with Law mentioning the Islamic Banking Sharia. For instance, banking means an institution performing either commercial or sharia based activities in providing services of payment traffic. It is also mentioned that shari'ah banks have extensive opportunities to run business activities, including those for conventional commercial bank to open a sharia branch office. Based on data from OJK (Otoritas Jasa Keuangan), until 2015, there were 2,881 branches of Islamic banking. ${ }^{12}$

Islamic banking grows and develops as an alternative to conventional banking practices. Critics of the concept of conventional banks are not in refusing its function as a financial intermediary. Instead, it is about other characteristics, such as the elements of usury, gambling (maysìr), uncertainty (gharar) and false (bāthil). As an alternative to replace those mentioned, Islamic traditional contract is used. Therefore philosophically, Islamic banks are banks with activities free from usury. ${ }^{13}$ This is in line with God's word in Q.S AlBaqarah [2]: 275:

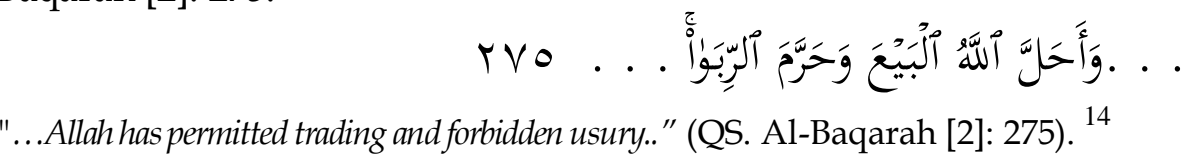

${ }^{12}$ www.ojk.go.id. Accessed on April 10, 2016.

${ }_{13}$ Amir Machmud, Bank Syariah: Teori, Kebijakan dan Studi Empiris di Indonesia, (Jakarta: Erlangga), 2010, 4.

14Departemen Agama RI, Al-Qur'an dan Terjemahnya, (Jakarta: J-ART, 2005), 48. 
The traditional Islamic contract, according to Muhammad Syafii Antonio, consists of: "Deposits, profit sharing, leases both operating and financial, and fee-based on service covering al-wakalah, al-kafâlah, al-hiwâlah, al-rahn, and al-qardl". ${ }^{15}$

Moslem's enthusiasm on the Islamic banking was in harmony with the development of Islamic economics in the legal field. Among others, it was signed by the birth of legislation such as Law No. 3 of 2004 on Bank of Indonesia and the Act Number 10 of 1998 on the amendment of Law No. 7 of 1992 about banking, Law No. 19 the Year 2008 regarding State Securities Sharia and Law 21 of 2008 on banking sharia. The aforementioned regulations are further strengthening Islamic economic activities up to present times. ${ }^{16}$

In the next process, the rise of Islamic business activities cannot avoid any dispute among involved parties. The dispute generally finds the settlement in both litigation in the courts and non-litigation through alternative dispute resolution. Certainly, each has advantages and disadvantages, yet the more important thing is how to settle any disputes with a quick, simple and light cost in accordance with Islamic principles. Therefore, the implementation of sharia principles in Islamic banking business activities and role of the court are both expected to escort the process using kâffah (at whole) and istiqâmah (consistent) concepts through court decisions to create justice, solidarity, and equity in economic activity.

The Islamic banking arrangement is based one the government's awareness and policy in regulation making process, particularly on the management of Islamic banking compared to conventional ones. ${ }^{17}$ Related to this, each of Islamic and conventional banking has regulation with clear limits. For example, conventional banks can

\footnotetext{
15Muhammad Syafi'i Antonio, 2007, Bank Syariah dari Teori ke Praktik, 10nd edition, (Jakarta : Gema Insasani Press and Tazkia Cendikia), 83. See also M. Natsir Asnawi, Menyoal Kompetensi Peradilan Agama dalam Menyelesaikan Perkara Ekonomi Syari'ah, (Jakarta: Media Badilag 2011), 4

16Afdol, Legislasi Hukum Islam di Indonesia, 115. See also Muhammad, 2005, Sistem dan Prosedur Operasional Bank Syariah, Yogyakarta, UII Press, 18 and Muhammad Djakfar, Hukum Bisnis, (Malang - UIN-Malang Press 2009), 37

17Mohamed Ariff, "Islamic Banking: A Southeast Asian Perspective", in Mohamed Ariff (ed.), Islamic Banking in Southeast Asia (Singapore: Institute of Southeast Asian Studies, 1988), 210.
} 
found a Sharia based branch but it needs a separation (spin-off) from the conventional aircraft within a certain time. ${ }^{18}$

Principally, political law has two dimensions. First is the basic policy which becomes the main reason for enacting certain legislation. Second is the purpose or reason behind the enactment. The second becomes interesting to discuss further because typically, those with authorities like to use any legislation as a political instrument.

The existence of Islamic banking and religious courts has a very close relationship. Islamic banking as a financial intermediary and religious courts as a special judicial institution with absolute authority equally emphasize to apply Islamic principles in their operation. Both are expected to synergize each other while maintaining the Sharia concepts of käffah (wholeness) and istiqāmah (consistency).

Juridically, the existence of both religious courts and sharia banking in Indonesia has a very strong legitimacy. However, within certain limits, they still serve as "alternative options". The most major issues on this are as follow. First is public stigma that sharia banking still has not fully implemented shari'ah guides in the practice and their exclusive customers among the Moslem only. Second is the authority to settle any Islamic banking dispute which only belong to Religious Court. In fact, religious court is generally cconsidered as those concerning with divorce ceases as if it is not competent to resolve sharia banking disputes.

The aforementioned stigma makes much sense at least from two factors. First, the existence of sharia banking in Indonesia's business is relatively new compared to the conventional banking. Second, religious court as the only court to settle any sharia banking disputes still tends to resolve other types of cases such as divorce. There are a very few Islamic banking disputes resolved in the religious courts.

\section{Principles for the Islamic Banking Settlement}

In Islamic law, the settlement of disputes can be through three ways. First is ishlāh/shulh (peace making). Ishlāh literally implies resolving any quarrels or disputes. Its definition, furthermore, is

${ }^{18}$ Muhammad Ramadhan, Politik Hukum Perbankan Syariah di Indonesia, MIQOT Vol. XL No. 2 July-December 2016, 273. 
mentioned in the formulation of Islamic law as follow: "A type of contract (agreement) to resolve any fight (dispute) between two parties". Peace making is highly recommended because it can avoid any broken relationship between the parties as well as any hostility. The suggestion for making peace among dispute involved parties is found in the Glorious Qur'an, Sunnah, and ijmä'. ${ }^{19}$

Each of parties involved in this peace making process is mentioned mushālih, while the object of dispute is referred to mushālih 'anhu. As for any action of one party to another for the purpose of resolving the dispute is called mushälih 'alayhi. Islamic teaching does suggests a peace making process because its existence between or among those in dispute could anticipate any break of social bond or so called silaturrahim. The teaching is well delivered in the Qur'an, hadith even $i j m \bar{a}^{\prime}$.

In this context, the peace making process has specific principles to properly resolve the dispute at the main point(s). Among others, it consists of fairness in making any decision related to the dispute so there will be no party who think of getting aggrieved. Another principle is kinship, and the next is win-win solution through making the dispute issue exclusively confidential for related parties. The last one, eventually, is resolving issues comprehensively in fair togetherness. $^{20}$

On the other hand, there also found some principles of sharia economy law in Islamic economic dispute resolution taken from figh mu'amalah. They are Islamic economic system and the economic system of sharia law. The former means a figh mu ämalah which consists of rules or the working mechanism which govern any economic effort made of individuals or legal economic entities. Meanwhile, the later refers to a figh mu'ämalah as a normative law that governs the economic rules. ${ }^{21}$

The nature and characteristics of sharia economic law cannot simply be examined solely from its methodology. It is mainly because

${ }^{19}$ Nurul Ichsan, Penyelesaian Sengketa Perbankan Syariah, dalam Jurnal Ahkam: Vol. XV, No. 2, Juli 2015, 232.

20 Ibid.

${ }^{21}$ Deni K Yusuf, Model Upaya Hukum Penyelesaian Sengketa Ekonomi Syariah, Laporan Penelitian (Bandung: UIN SGD Bandung, 2014), 43-45 
in the terminology of Indonesian Islamic law, there recognized three legal forms, i.e Islamic law, customary law, and the West law. Each is an independent legal form with different methods for further study purpose.

The foundational differences among Islamic, customary and the Wes Laws are not only in the sense of both origin and materials of the law, but also components included in the legal research field. If Islamic law contains vertical and horizontal dimensions because it was born from both divine revelation and realities, customary and the West law are almost entirely based from tradition and rational thinkings. On the basis of it, the main principles of Islamic banking dispute settlement, among others, are as follow:

1. Eliminating parochialism/Not giving too much burden

This principle is very clear in the process of establishing Islamic law. Generally, each established law needs to show that its existence and role are nothing but to provide convenience and relief. It is basic human nature to dislike any burden that limits the right for freedom. They also like to pay attention carefully on the law. Meanwhile, in obeying the law, their own choices lead them to choose whether they are able to do so.

On the basis of it, Sharia economic law is enforced in accordance with the nature of human and not solely based on the will of Allah. This aims to make everyone intentionally leads themselves on tolerance, equality, independence and amar ma'rûf nahy munkar. The enactment of Islamic law is not stiff (rigid). Instead, it can can adapt to any situations and conditions flexibly. Therefore, a fiqh basic rule says, "any change of law is affected by situations and conditions, and by the time and place". ${ }^{22}$

2. Minimizing the Burden

The principle of minimizing the burden in the Islamic law is not only intended to fulfill any needs and events requiring legal provisions. Furhtermore, Islamic law is not only to respond these issues at the time, but rather as guidance to deal with any new problems in the future. Although people

22Ibnu Qayyim al-Jauziyah, I'lam al-Muwaqqin, jilid III, (Beirut: Dar al-Fikr, s.a), 14. 
have different abilities in responding to the enactment of Islamic law, the main consideration is to minimize the burden, as it is clear at the following:

"It is allowed to do any mu'âmalah activities unless there is an evidence saying it as forbidden ". Based on the rule, there is nothig to do with any statement mentioning that Islamic law is incriminating. Instead, the elasticity of Islamic law will relieve all the law burdens". ${ }^{23}$

3. Establishing the Law Gradually

The gradual establishment of Islamic law is the main principle which had occured at the prophet era. It is believed that every binding law establishment has a historical background and reasons for its enactment. The philosophy of the gradual process is to make easier in identifying both essence and material of the legal matter as well as strengthen the understanding appropriate to the circumstances.

4. Paying Attention to People Benefit

Islamic law's legal provisions have specific reasons, argument and purposes for the sake of human benefit. Generally, the argument is much more about interpersonal relationship as a manifestation of human relationships with their creators. The establishment of Islamic law is mainly based on three joint principals. First, the laws are set to fulfill the needs of law. Second, the laws are established by a certain authority with the specific privelege and forcing power for public. Third, the laws are established in accordance with the human ability levels to obtain the benefit appropriate to the objectives of Islamic law (maqâshid al-sharia).

5. Creating Well-Spreaded Justice

The principle of justice is actually the main foundation for the law enforcement. People are equal before the law, and Islamic law provides strict punishment for any rule breakers without exception. Among the legal principles to consider in implementing the law are as follow. First is enacting justice for the sake of human rights. Second, the

${ }^{23}$ A. Jasuli, Pengantar Ilmu Figh, (Jakarta: Radjwali Press 1994), 20-23. 
law aims for welfare and prosperity of society. Third, the law enactment is accordance with the proportionality and the ability level of each person. Fourth, any violation of the law should be punished fairly and wisely. Fifth, it needs to foster a belief that every unlawful activities are those against the provisions of Allah and His Messenger. ${ }^{24}$

\section{The Philosophy of Islamic Banking Dispute Resolution}

Islam also recognizes the existence of legal justice or justice under law. ${ }^{25}$ Justice is an unseparable term in legal terminologies because it is the substance of the law itself. As a consequence, the implementation of law needs to get adjusted to the purpose of law established in God's revelation. However, justice can be relative because according to the laws, it is determined by the rules of a formal/procedural and social customs regulations. The more any formal rules are enacted, the more it possibly creates a real injustice when the decision is contrary to the "spirit" of the law. Therefore, there found a specific term called substantive justice to describe any justice in line with the spirit of the law. ${ }^{26}$

The substantive justice is an internal part of the law. It contains unsures of justice which underlie a statement on any action whether it is right or wrong or so called haläl and haram in Islamic terminologies. Based on this, any obligation needs to reflect justice from God's will while any prohibition should be unfair thing/action from the perspective of the purpose of law, which is for the sake of general interest and common goodness (maslahah) that need protection.

At the next developments, under the influence of Greek philosophers, especially Plato and Aristotle, early Moslem thinkers like Ibn Hazm and Ghozali argued that "the ultimate goal of the law is happiness in the world and hereafter." ${ }^{27}$ Meanwhile, according to Islamic principles, "relating to social relationshop, those who are

${ }^{24}$ Hasbi Ash- Shiddiqie, Fakta Keagungan Syariat Islam, (Jakarta: Bulan Bintang, 1982), 25-26.

25Masjid Khadduri, Teologi Keadilan dalam Perspektif Islam, (Surabaya: Risalah Gusti , 1999), 135.

26Ibid. 136.

27Ibid. 140 . 
commited for fairness need to enact the principles of freedom, equality, tolerance, and brotherhood." 28

The principles of brotherhood and equality are the the most fundamental basic in social interaction. Moreover, they are more important than the principle of freedom because freedom on each individual should be implemented in an atmosphere of togetherness and brotherhood and the spirit of tolerance not only as a moral basis but also a religious obligation. Based on this, the Islamic banking contract require whole parties to respect and uphold the rights of others. Related to this, the principle of fairness also has implications for the demand of justice in the economic system of a real society.

The vital and central value of justice in a society led Ibn Taymiya to say so: "If any worldly affair is governed by justice, people will be physically and spiritually healthy even though they have rulers with bad morality. If it is governed by tyranny, society will collapse regardless of personal mistakes of rulers which become their own responsibilities in the hereafter. The worldly affairs will be well done by justice even if there is no religion. On the contrary, it will collapse because of injustice even if accompanied by Islam". ${ }^{29}$

Based on the notions mentioned above, justice according to Islamic perspective is the fairness ringht from the motive/ intention/goodwill, processes and objectives. Justice also contains universal basic principles. It is a natural demand of human social life in modern times. In spite of its universality, the real implementation of justice would necessitate consideration on the demands of space and time. This shows that the modern era is different from agrarian era and therefore, failure to understand the terms of this difference will result in failure in efforts to apply the justice itself.

History records that wherever Moslems live, there certainly found a judicial institution. Since the era of the Prophet Muhammad which Islam began to grow and develop, the forerunner of the judicial system was already founded. Later on, at the era of companion, the judiciary institution had even been found even with very simple form.

28Morris Ginsberg, Keadilan dalam Masyarakat, (Yogyakarta: Mandiri, 2003), 142.

${ }^{29}$ Erie; Suyudi Mohammad Hariyanto, "View of Jual Beli Benda Wakaf Untuk Pembangunan Masjid Istiqlal Di Desa Palengaan Daja Pamekasan," accessed December 2, 2019,

http://jurnalfsh.uinsby.ac.id/index.php/aldaulah/article/view/665/531 
The existence of Islamic banking can fulfill various needs of community without any doubt on whether it is allowed to use banking service from Islamic perspective. It is mainly because the criticism of Islamic banking system against conventional banking is not in terms of its function as an intermediary financial institution, but the existence of prohibited elements in its operation.

Islamic Banking, therefore, is a bank running its business based on sharia principles. According to the type, it consists of Islamic banks and sharia finance bank. Thus, Islamic bank is a bank conducting its business activities based on Islamic principles. The principles are based on fatwa issued by authoritative institutions in formulating fatwa in the field of sharia. The principles contains two meanings, namely the principles of Islamic law in banking activities and the general principles of Islamic law. However, the later does not solely refer to a pure figh mu àmalah, but the principles of Islamic law based on the fatwa issued by the authoritative institution.

A context of the most recent modern times puts people in a big tug between two great ideologies namely capitalism and socialism. Moslems seek their own identity with an Islamic based ideology. It is all mentioned at and supported by the sources of Islamic teachings, especially The Quran as a guide in the discussion on Islamic banking dispute resolution at the religious courts.

\section{Conclusion}

The philosophical basis of the authority of religious court in sharia banking dispute resolution is to create harmony between the implementation of the agreement and the substantive law. It is based on Islamic principles and conducted through religious court which provides a venue as well as service for Moslems justice seekers in dealing with Islamic banking disputes to resolve it wholly (kafāah) and continuously (istiqāmah).

\section{Bibliography}

Abdurrahman, Eksistensi Perbankan Syari'ah dalam Pembinaan Ekonomi Umat dalam Prospek Bank Syariah di Indonesia, PPHIM, Bandung, 2005. 
Afdol, Landasan Hukum Positif Pemberlakuan Hukum Islam dan Permasalahan Implementasi Hukum Kewarisan Islam, Airlangga University Press, Surabaya, 2003

Ash-Shiddiqie, Hasbi. Fakta Keagungan Syariat Islam, Jakarta: Bulan Bintang, 1982

Asnawi, M. Natsir. Menyoal Kompetensi Peradilan Agama dalam Menyelesaikan Perkara Ekonomi Syari'ah, Media Badilag tahun 2011.

Antonio, Muhammad Syafi'i. Bank Syariah dari Teori ke Praktik, Cetakan ke-10, Gema Insasani Press dan Tazkia Cendikia, Jakarta, 2007

Cendikiawan, Tazkia Institut, 1999.

Al-Hakim, Sofyan, Perkembangan Regulasi Perbankan Syariah di Indonesia, Jurnal Ijtihad, Volume 13, No. 1, Juni 2013.

Ariff, Mohamed. "Islamic Banking: A Southeast Asian Perspective", dalam Mohamed Ariff (ed.), Islamic Banking in Southeast Asia (Singapore: Institute of Southeast Asian Studies, 1988).

Ali, Mohammad Daud dan Habibah Daud, Lembaga-lembaga Islam di Indonesia, Raja Grafindo Persada, Jakarta, 1995.

Bank Indonesia, Panduan Investasi Perbankan Syariah Indonesia, Jakarta: Bank Indonesia, 2007.

Departemen Agama RI, Al-Qur'an dan Terjemahnya, t.t.: J-ART

Ginsberg, Morris. Keadilan dalam Masyarakat, Yogya Mandiri, Yogyakarta, 2003.

Hariyanto, Erie. "The Political Scrimmage of The Religious Court's Law as The Judicial Institution In The Reformation Era In Indonesia." AlIhkam: Jurnal Hukum \& Pranata Sosial 11, no. 1 (July 3, 2016): 178. https://doi.org/10.19105/al-ihkam.v11i1.782 -."Kedudukan Bank Syariah dalam Sistem Perbankan di Indonesia" in Iqtishadia: Jurnal Ekonomi dan Perbankan Syariah STAIN Pamekasan, Vol. 3 No. 2 Desember 2016

Hariyanto, Erie; Suyudi Mohammad. "Jual Beli Benda Wakaf Untuk Pembangunan Masjid Istiqlal di Desa Palengaan Daja Pamekasan." http://jurnalfsh.uinsby.ac.id/index.php/aldaulah/article/view $\angle 665 / 531$.

Hamami, Taufiq. Peradilan Agama dalam Reformasi Kekuasaan Kehakiman di Indonesia, Jakarta: Tatanusa, 2013 
Jasuli, A. Pengantar Ilmu Figh, Jakarta: Radjawali Press 1994

al-Jauziyah, Ibn Qayyim. I'lam al-Muwaqqin, Beirut: Dar al-Fikr, t.th

Khadduri, Madjid. Teologi Keadilan dalam Perspektif Islam, Risalah Gusti Surabaya, 1999

Mannan, Abdul. Hukum Perbankan Syariah, Jurnal Mimbar Hukum dan Peradilan, Vol. 1, No. 7, 2012.

Machmud, Amir. Bank Syariah: Teori, Kebijakan dan Studi Empiris di Indonesia, et. Al. t.t.: Erlangga, 2010

Mardani, Hukum Acara Perdata Peradilan Agama, Jakarta, Sinar Grafika, 2007.

Perwataatmadja, Karnaen. Bank dan Asuransi Islam di Indonesia, Kencana, 2005, Jakarta

Ramadhan, Muhammad. Politik Hukum Perbankan Syariah di Indonesia, MIQOT Vol. XL No. 2 Juli-Desember 2016

Saeed, Abdullah. Menyoal Bank Syari'ah. Jakarta: Paramadina, 2004.

Warka, Made, and Erie Hariyanto. "Kedudukan Bank Syariah Dalam Sistem Perbankan Di Indonesia." IQTISHADIA: Jurnal Ekonomi \& Perbankan Syariah, 2016. https:// doi.org/10.19105/iqtishadia.v3i2.1076.

Yusuf, Deni K. Model Upaya Hukum Penyelesaian Sengketa Ekonomi Syariah, Laporan Penelitian UIN SGD Bandung, 2014.

Zahriah, Erfaniah. Peradilan Agama Indonesia: Sejarah Pemikiran dan Realita, Malang: UIN Maliki Press, 2009 